\title{
Russian Federation President's Prize Awarded to S. V. Krivovichev
}

PACS numbers: $01.60 .+\mathrm{q}$

DOI: $10.1134 / \mathrm{S} 1066362209020234$

On February 9, 2009, RF President D.A. Medvedev in the Kremlin presented the RF President's Prize in the Field of Science and Innovations for Young Scientists to Professor, Doctor of Geological and Mineralogical Sciences Sergei Vladimirovich Krivovichev. The main field of scientific activities of S.V. Krivovichev is study of new minerals, nanomaterials, and substances with useful properties. In cooperation with S.K. Filatov, he created a new line of crystal chemistry: crystal chemistry of minerals and inorganic compounds with anion-centered complexes. Krivovichev prepared and studied more than 200 new substances and minerals, including uranium oxide nanotubes, the world's first nanostructures based on uranium. In cooperation with researchers from Russia and other countries, he discovered 34 new minerals.

Krivovichev is an author and co-author of more than 300 scientific works, including four monographs and more than 200 articles in the leading journals of Russia and other countries, in particular, in Radiokhimiya/Radiochemistry. Krivovichev is a member of editorial boards of the journals Vestnik $S P b G U$, Seriya Geologia, Geografiya (Bulletin of the St. Petersburg State Univ., Ser.: Geology, Geography), Zapiski Rossiskogo Mineralogicheskogo Obshchestva (Proc. Russian Mineralogical Society), Canadian Mineralogist, and American Mineralogist, and also co-chairman of the Section of Inorganic Structures of the European Crystallographic Association. Krivovichev repeatedly won grants of the Russian Federation President for young candidates and doctors of sciences. He was awarded with a medal and prize for young scientists of

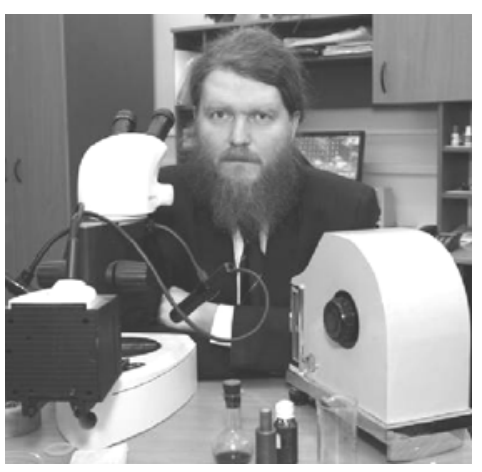

the Russian Academy of Sciences (2001); gold medal and prize of the Alferov Foundation for Support of Education and Science (2004); medal of the European Mineralogical Union for Research Excellence (2002); medal and prize of the European Academy of Sciences (2004); Struchkov Prize for the best work in the field of crystal chemistry (2005), and others. An acknowledgment of Krivovichev's scientific is that a new mineral krivovichevite was named in his honor. This name was approved in 2005 by the International Mineralogical Association. Three candidate's dissertations were defended under Krivovichev's guidance. He actively participated in implementation of an innovation educational project of the St. Petersburg State University (Education National Project) within the framework of the program "Innovation Educational Environment in a Classical University."

The Radiokhimiya/Radiochemistry journal congratulates Sergei Vladimirovich on the high award and wishes him new scientific achievements. 